\title{
ARCHITEKTŪROS IR URBANISTIKOS OBJEKTŲ NATŪROS TYRIMŲ METODIKOS PROBLEMOS
}

\author{
Robertas Zilinskas \\ Urbanistikos katedra, Urbanistinès analizés laboratorija, \\ Vilniaus Gedimino technikos universitetas, Pylimo g. 26/Trakug. 1, \\ LT-01132 Vilnius, Lietuva, el. paštas: bebop@inbox.lt \\ Iteikta 20090330
}

\begin{abstract}
Santrauka. Nagrinejjamos niekad anksčiau publikacijose nenagrinètos architektūros natūrinių tyrimų problemos. Yra žinomi 5 atvejai, kai bandyta parengti tokių tyrimų normatyvus, visų bandymų produktai yra iš dalies išlikę ir saugomi Vilniaus apskrities archyve. Pateikiamas šių bandymų nagrinėjimas ir pasiūlymai, paremti straipsnio autoriaus 22 metų asmeniniu įdirbiu tyrimų srityje, kaip pritaikyti kolektyvinę pirmtakų ir savo patirtị nustatant natūros tyrimų principus dabartinèmis paveldosaugos sistemos sąlygomis.

Reikšminiai žodžiai: stilistinè restauracija, atkūrimas, taikomieji moksliniai tyrimai, istorinès ir meninès raidos tyrimai, autentiškumas, vertingoji savybė, ikonografija, paveldas, paveldosauga, evoliucija, zondavimas, restauravimas, konservavimas, įvaizdis, užstatymo morfotipas, aksiologiniai tyrimai, polichromijos paieškos, kartograma, vektorinė programa, GPS, LKS, 3D skenavimas, ardomieji tyrimai, autorių teisés, datavimas, indukcija, dedukcija, giluminis zondavimas, simetrija, tipiškumas, lauko darbai, kameraliniai darbai.
\end{abstract}

\section{Ivadas}

Lietuvos architektūros natūros tyrimų disciplinai šiemet sukaks $60 \mathrm{~m}$. (nuo 1949 m.). Iki tol architektūros paveldo tvarkyba buvo vykdyta remiantis stilistiniais principais. Tai yra geriausiu atveju iš rašytinių šaltinių sužinojus bendrą objekto datavimą buvo stengiamasi išlaikyti atitinkamos epochos stilistikos bruožus (pavyzdžiai: 1905-1912 m. Z. Hendelio ir 1933 m. S. Lorenco Šv. Mykolo arkangelo bažnyčios rekonstrukcija, 1939 m. S. Narembskio Rotušès rekonstrukcija Vilniuje). Toks metodas pradejo vystytis, matyt, ne vèliau kaip nuo XVIII a. galo (ar net anksčiau, nuo XVI a.), kai remtasi prielaida, kad Lietuva yra sulaukèjusi ir užmiršusi savo šaknis Romos imperijos kolonija, todèl yra šaunu jos architektūros paveldą normalizuoti pagal Romos orderinius principus (pavyzdžiai: L. Stuokos-Gucevičiaus nuo 1783 m. Katedros ir 17851799 m. Rotušès Vilniuje rekonstrukcijos).

Bandymus unifikuoti natūros tyrimų metodiką darę specialistai yra prieškario arba ankstyvojo pokario kartų atstovai. Sovietinių metų pradžioje èmus persekioti krikščionybę ikikrikščioniška kultūra tapo viešai neskelbiama alternatyva viešam respektavimui, todèl ankstyvųjų jos raiškos atvejų paieškos tapo savotišku neviešinamu tyrëjų tikslu. Visas mūsų kultūros daugiasluoksniškumas ir autentiškumas neretai aukotas gotiškoms ir ikigotiškoms (jeigu tokių buvo) mūro formoms eksponuoti, o kai tokių buvo randama mažai - atkurti (pavyzdys: 1977 m. E. Urbonienès „Naručio" viešbučio restauracija Vilniuje). Tokios tendencijos, palaikomos vis dar aktualių anų kartų visuomenès veikejų, vis dar tebèra gajos (pavyzdys: iki šiol tebesitęsiantis A. M. Brazausko valdovų rūmų „atkūrimas“ Vilniuje).

Šio straipsnio tikslas nèra prikaišioti praeities ir šiandienos paveldosaugininkų klaidas, juolab kad daugelis jų veikè ir tebeveikia iš visiškai nuoširdžių paskatų, savo siekiams igyvendinti aukodami daug energijos. Laikykime visa tai taip pat istorija ir, apžvelgę bandymus metodologiškai pagrịsti tokią veiklą, apibendrinkime juos remdamiesi naujausia šios srities patirtimi bei pasaulinèmis tendencijomis. 
Straipsnyje pateikiamivisųžinomų Lietuvos natūros tyrimų metodikos ieškotojų teiginiai, sugrupuoti pagal skirtingus metodikos klausimus. Jie pateikiami konspekto pavidalu, nes labai nevienoda skirtingų autorių medžiagos struktūra, joje, kaip ir priklauso tyrèjams, akcentuotos detalès, kuriomis negalime užkrauti riboto dydžio straipsnio. Lyginami skirtingų autorių požiūriai ir bandoma i juos žiūrèti iš šiandienos pozicijų.

Toliau bus rašoma tik apie $2005 \mathrm{~m}$. LR nekilnojamojo kultūros paveldo apsaugos įstatymo apibrežtų taikomujų moksliniu tyrimu tais pačiais metais LR kultūros ministro ịsakymu İV-259 patvirtintame apraše minimų istorinès-meninès raidos tyrimu pobūdžio architektūros ir urbanistikos tyrimus. Straipsnyje problematika nagrinëjama pagal jos atsiradimą šaltiniuose pradedant nuo anksčiausio, chronologiniu nuoseklumu, kuris yra lyg ir mechaniškas, bet savaip atspindi problemų svarbą per jų iškilimo chronologiją.

Gal straipsnio problematika yra perdèm specifiška, neverta tiketis, kad dauguma jo skaitytojų tiek ja susidomès, kad apsispręs specializuotis ị šią sritị, ir to visai nereikia, bet architektūros paveldo objektų pritaikymo ir urbanistikos objektų regeneravimo problemas sprendžiantiems projektuotojams būtų pravartu su ja susipažinti. Jeigu ši problematika artimiausiu metu liks nesuprasta - nieko baisaus - nesuprasta šešis dešimtmečius, ji gali palaukti savo eilès dar vieną kitą dešimtmetị, tyrimų darbas dèl to nesustos. Galima ị pateikiamą straipsni žiūrèti tiesiog kaip ị bandymą atlikti savo pareigą.

\section{1. Šaltiniai}

Straipsniui sąmoningai pasirinkti tik tie šaltiniai, kurie yra tiesiogiai susiję su svarstoma problematika. Natūros tyrimų metodikos klausimu Lietuvoje nieko nèra publikuota. Nė vienas iš autorių neturi jokių mokslinių titulų, nes buvo nuolat užsièmę išgyvenimu iš prestižo neturinčios veiklos, atimančios visą laiką ir sveikatą (menkai apmokamas sunkus fizinis darbas, šaltis, dulkès, traumos, viešas pažeminimas), ir nuolat abejojama jų veiklos moksliškumu.

Dalis Vilniaus apskrities archyve (VAA) buvusios šiuo klausimu medžiagos prarasta: D. Zareckienès liko tik santrauka rusų kalba, nebera T. Garonaitès išrašų apie Lenkijos PKZ (Pracownie Konserwacji Zbytków) imonès tyrimų metodiką. Didesne dalis informacijos liko žodinès tradicijos formos. Toks autoritetas kaip S. B. Lasavickas (1926-1998 m.), laikomas vienu iš disciplinos pradininkų Lietuvoje, išvis nieko apie tyrimų metodiką nèra parašęs, nes to padaryti jam neleidusi visiškai pašlijusi sveikata, bet kalbèdavo jis daug ir noriai. Kitas iš pradininkų - tebedirbantis Ž. Simonaitis (buv. Simonavičius), sakydavęs turịs paruoštą metodi$\mathrm{ką}$, bet nenorịs jos lengvai perleisti nebrandžiai visuomenei, nors kolegoms nešykštėdamas gyvai perduoda visas savo žinias, kurias nuolat papildo, savo metodikos principus nuolat tobulina. Jo mokiniu save laikantis E. Purlys tvirtina nesant etiška viešinti savo metodikos principus, kol to nepadarè mokytojas, tačiau E. Purlio mokiniais save laiko didžioji dalis paskutinès tyrejų laidos, kuri nebepasipildo nuo perestroikos laikų.

Bet žodinè tradicija tebegyvuoja.

\section{Aktualumas}

Natūros tyrimai yra vieni iš svarbiausių paveldosaugoje, nes jų pagrindinis uždavinys yra nustatyti autentiškumą, kuris yra pagrindinè bet kurio kultūros paveldo objekto vertingoji savybè, be jos jokios kitos savybès neturi reikšmès. Lietuvos architektūros paveldo ypatybès: vèlyva raštija, menkas jos šaltinių ir paties paveldo išlikimas dèl istorinių sukrètimų gausos, ypač nepalankaus klimato, nuolatinis dèl to atsiradęs radikalus statinių ir urbanistinių struktūrų kitimas daugeliu atvejų natūros tyrimus daro net svaresnius už istorinius ar ikonografinius, o neretai ir vienintelius, galinčius duoti informacijos rūpimais klausimais.

Yra didelis įdirbis tobulinant tyrimų igūdžius, bet dèl pripažintos metodikos nebuvimo neretai abejojama jų patikimumu, pavyzdžiui, teismuose, besibylinèjant dèl nekilnojamojo turto. Valstybei vis toliau einant teisine linkme, o nuosavybei igaunant vis daugiau šventumo, tokie natūros tyrimų uždaviniai darosi vis aktualesni, ir tai yra kraštutinè besiplečiančios natūros tyrimų problematikos diapazono riba, apie kurią net baisiausiuose košmaruose nesapnavo legendiniai šių tyrimų disciplinos pradininkai ir entuziastai. Kultūros ministro patvirtintuose reglamentuose teisingai reikalaujama bet kuriuos paveldosaugos tvarkomuosius veiksmus grịsti būtent natūros tyrimų duomenimis, 0 apibrèžtų tokių tyrimų principu jis nèra patvirtinęs, nes jie nèra apibrèžti.

Tampant kriminalistikos talkininkais nekilnojamojo paveldo tyrimams teks igauti kriminalistikos metodų precizikos, ir tai gali būti naudinga jų kokybei. Iš tiesų sąžiningai dirbantis tyrejjas kaip tik turètų vadovautis kriminalistikos principais. Natūros tyrimai yra įkalčių rinkimas ir įrodymų formulavimas kiekvieną kartą priklausomai nuo konkretaus uždavinio ir situacijos, kurios retai kartojasi. Tik tyrejo pastabumas, nuoseklumas ir igudimas gali lemti gerą 
rezultatą. Kiekvienas ne iki galo įrodytas atvejis turi baigtis probleminiu ataskaitos pateikimu, taip būtų išvengta klaidingų išvadų įtvirtinimo, nauji paskui iškilę ịkalčiai turi būti pripažinti. Nuolatinis viešas savo klaidų pripažinimas ir taisymas turetų tapti mokslo etikos imperatyva.

\section{Tikslai}

Simonavičius, Ž., 1960: mokslinè ir technine dokumentacija (iskaitant tyrimu) yra restauravimo pagalbine priemone.

Urboniene, E., 1971: tyrimu tikslais priklausomai nuo ju detalumo gali būti išsiaiškinti sklypo užstatymo evoliucija, atskirų korpusų vertę, išskirti saugotinus pastatus bei ju fragmentus, vertingus elementus, išsiaiškinti atskiro pastato evoliucija, atsekti visas išlikusias autentiškas detales ar jų pédsakus, pirminę planinę struktūrą, fasadu sprendima.

Purlys, E., 1972: remiantis tokia (tyrimu) medžiaga rengiamas restauracijos projektas. Tai galutinis tyrimy tikslas. Tyrimu metodikos pagrindinis tikslas - gauti maksimuma informacijos iš kiekvieno zondo ir šurfo.

Drema, V., 1975: mūro zondavimo uždaviniai: pirminès statybos technikos ir jos išlikimo nustatymas, pirminiu konstrukciniu ir stiliaus formu pažinimas, vèlesniu rekonstrukciju müro technikos skirtumu atskleidimas, visu vèlesniu rekonstrukcijų architektūriniu ir stilistiniu formu katalogo sudarymas, planinès struktūros ir funkciju raida, visu techniniu ir architektūriniu pakeitimy chronologijos nustatymas, vertingiausio ir geriausiai išlikusio raidos etapo, pažeidimu priežasčiu nustatymas.

Zareckiene, D., 1987: paminklo tyrimu medžiaga yra restauravimo ir konservavimo projekto mokslinis pagrindas, todèl itin svarbu nustatyti bütina architektūros tyrimu apimti, technologiškai teisinga ir su minimaliomis darbo sąnaudomis, todèl bütina laikytis fiksavimo ir apipavidalinimo formos. Šiuo tikslu PRPI (Paminklu restauravimo projektavimo institutas) suküré oficialiq metodika.

Vyraujančiu tikslu laikytas duomenų tiekimas restauracijai. Tai nenuostabu, nes visi autoriai dirbo restauravimo institute, todel dirbo jam arba buvo su juo susiję. Metodikos rengimo tikslingumas diktuotas imonès veiklos kryptingumo, daugelis bandè sukurti metodiką tiesiog kaip žinybos instrukciją. Pokario laikmečio tendencija - buvo pereinama nuo stilistinès restauracijos prie autentiškų liekanų studijomis motyvuotos restauracijos, nors kai kurie projektuotojai iki pat karjeros pabaigos atkakliai dirbo stilistinès restau- racijos kryptimi (ryškiausias atstovas - V. Gabriūnas, 1930-1992 m.). O tokia tendencija tebegyvuoja iki šiol, tik ji dabar vadinama epochos, stiliaus ịvaizdžio atkūrimu ar panašiai.

IX-ajame dešimtmetyje dèl tarptautinių paveldosaugos principų imta ị konservaciją žiūrèti kaip ị prioritetinę krypti, nors tai ir iki šiol nèra iki galo įsisąmoninta. Taip 1987 m. D. Zareckienès metodikoje tyrimų tikslu pasirinktas mokslinio pagrindo restauravimo ir konservavimo projektui parengimas.

E. Urbonienès $1971 \mathrm{~m}$. tyrimų tikslai ne tokie žinybiški, platesni, nuoseklūs, einantys nuo visumos link detalių ir iš pirmo žvilgsnio nepriklausomi. Tuo metu Vilniaus Senamiestį užsimota tvarkyti planingai, ištisais kvartalais. Jis jau tyrinètas kvartalais pradedant nuo maždaug 1960 m. (pasižymèjo R. Jaloveckas, vèliau šalia E. Urbonienès - R. Jarmalavičienè). Buvo atliktas tikrai didelis darbas, tačiau ir būdami itin ištikimi savo specializacijai tyrejjai tarp tyrimų tikslų nepaminejjo verčių ir saugotinų objektų išskyrimo. Mat atlikus kvartalų tyrimus būdavo „susipažinimai su objektais“, „pagrindimai“ ir „ivertinimai“, kuriuos darydavo labiau projektavimo srityje specializavęsi architektai, turëję visą kvartalų užstatymą sugraduoti pagal vertingumą. Paprastai ne tokiu vertingu būdavo pripažịstamas vèlesnis ir smulkesnis užstatymas kvartalų viduryje, tik daug vèliau imta svarstyti apie antrarūšio užstatymo urbanistinę vertę, užstatymo morfotipus. Dori tyrèjai ilgą laiką buvo išnaudojami pagrịsti manevravimo bokštiniais kranais ir lauko inžinerinių tinklų išdèstymo patogumą, o visa paveldotvarka ilgai ir tvirtai laikèsi fasadinès krypties - juk klestëjo brandus socializmas.

Tyrejai ir dabar išnaudojami utilitariems tikslams, nes dabartinio privataus pragmatizmo ir pletros sąlygomis dažniausiai net nesvarstomi panašūs ị restauravimą ar konservavimą motyvai, tyrimų tikslu vis labiau tampa pritaikymo galimybių pagrindimas, o kadangi tokia realybè yra visiškai neišvengiama, tyrejjams lieka tik nesileisti spaudžiamiems nepreciziškai ir neobjektyviai atlikti savo darbą.

V. Drèma (1910-1995 m.) 1975 m., būdamas dailètyrininku, architektūros tyrimų tikslus nuvertina iki „mūro zondavimo uždavinių“. Jis ypač rūpinosi savo kastos prestižu, architektus laikè potencialiais kultūros paveldo niokotojais. Ir tai buvo be galo apmaudu, nes juk be architektų pagalbos to paveldo neimanoma išsaugoti. Tačiau buvo ikisovietinès dailètyros mokyklos atstovu, o juk „dailètyros" sąvoka ir sovietiniais laikais nebuvo žinoma į vakarus nuo Lazdijų, ten ir tamsiausiais laikais tai, ką mes tebevadiname „dailètyrininkais“, buvo ir tebèra vadinama „dailès istorikais“. 
Pastarasis specialybès pavadinimas ịpareigoja vietoj interpretavimų ir sintetinimų užsiimti žymiai žemiškesne veikla, kuri, ko gero, labai pažemintų dabartini posovietinį dailètyrininką. V. Drèma kaip tik ir užsiimëjo tokia kasdieniška veikla, kuri oficialiosios dailètyros vadinama ,juodu darbu“. Beveik tokio juodumo, kokio yra architektūros natūriniai tyrimai. Jis (V. D.) ypatingas buvo jau vien tuo, kad pripažino natūros tyrimų svarbą teigdamas, kad „natūros paieškos duoda išsamiausią informaciją“. Apibendrinant V. Drèmos kriterijus galima teigti, kad jis tyrimų uždaviniais laike verčių atskleidimą ir ju išsaugojimą. Tai tikrai abstrakčiu mąstymu, kurio vis trūksta paveldosaugininkams, apdovanoto intelekto motyvai.

Dar jis šiek tiek orientavosi ir ị veiklos planingumą, nes kaip tyrimų apibendrinimo produkto ragino siekti istorinių medžiagų, konstrukcijų ir stilistinių formų katalogų, kuriais galima būtų remtis ateities tyrimuose, sudarymo ir nuolatinio tokių katalogų papildymo naujais duomenimis. Panašiai nuo seno elgiasi archeologai, radinių katalogais grindžiantys visas savo išvadas, iš esmès tai sudaro archeologijos srities moksliškumo pagrindą. Gali būti, kad jei neseksime pripažintu jų metodu, ir toliau rizikuosime sužlugdyti savo pretenzijas ị „moksliškumo“ pripažinimą.

Dar apie vertinimą: galiojantis ịstatymo ịgyvendinamasis aktas (IV-259) yra ịtvirtinęs tokią tyrimų rūšį kaip vertinamojo pobūdžio (aksiologiniai) tyrimai ir priskyręs juos prie neardomųjų tyrimų. Būtina pastebèti, kad architektūros tyrèjas, natūroje vykdantis ardomuosius tyrimus, su kiekvienu plaktuko smūgiu priverstas užsiimti vertinimu - ar vertingiau atidengti eilinį apdailos sluoksnị, ar jị išsaugoti. Todèl ardomųjų veiksmų atlikimas yra aukščiausios kvalifikacijos reikalaujantis tyrimuc etapas, kurio negalima patiketi padieniam darbininkui, kaip buvo praktikuota restauracijos aukso amžiuje. Mat kaip jau užsiminta straipsnio pradžioje, $\mathrm{XX}$ a. antrojoje puseje viskas, kas nèra gotika, laikyta vertinga tik jeigu yra dekoruota. Todèllaikyta, kad jeigu polichromijos tyrejjas patikrino objektą ir nieko vertingo nerado - ji (objektą) galima drąsiai lupti iki mūro. Po tokios praktikos atsirado keistų apibendrinimų, neva, pavyzdžiui, Lietuvoje išvis beveik nebuvo renesanso, nors teturint vien bendrąjj išssilavinimą ir vien užmetus akị $i$ T. Makovskio $1600 \mathrm{~m}$. Vilniaus panoramą kyla visai priešingų minčių.

\section{Dokumentavimas}

Simonavičius, Ž., 1960: tyrimu dokumentavimas tekstų, piešiniu, brèžiniu, fotonuotrauku ir autentišku medžia- gų pavyzdžiu pavidalu turi būti tinkamas sprendžiant konkrečius uždavinius, reikalauti minimaliu sąnaudų, laiko ir energijos, būti tinkamas archyvuoti, dauginti ir publikuoti be papildomo apdorojimo. Reikia stengtis apsieiti be juodraščį, kuo daugiau fiksavimo galutiniu pavidalu atlikti objekte, kai ìmanoma, tenkintis fotografavimu. Tik itin atsakingais atvejais fiksuotini atskiri zondai ar elementai, kai imanoma, fiksuotina tiesiai ant matavimu brëžiniu, taip sutaupoma laiko. Dokumentavimo medžiagoje turi būti minimumas, bet ne mažiau faktu, datų, matmenu, skaičiu, detaliu, pastabu, išvadu, nurodymu, tikslumo.

Urboniene, E., 1971: zondu (originale - „zondažuূ“aut.pas.) piešimas (originale - „užpiešimas“-aut.pas.) pradètinas padarius objekte diduma atodangu („zondažu“" - aut. pas.). Geriausia, kai tai daro tiriantis architektas, bendradarbiaudamas su istoriku. Nebūtina piešti visu, o tik charakteringiausius zondus, kuriuose atsiskleide daugiausia informacijos. Restauravimo darbo brëžiniams parengti darytini archeologiniai matavimai, dèl kuriu ištisai atidengiamas dideliu plotu mūras. Atskiru laikotarpiu mūrai aprašomi mūro kortelese, kuriu yra kelios formos. Kortelèse yra, greta kitu , argumentu“ ir „išvadu“, skiltys. Zondai numeruojami, ju vietos žymimos schemose. Charakteringi zondai dar ir fotografuojami. Remiantis zondu ir müro kortelemis sudaromos stilistines planu kartogramos, jeigu reikia - ir fasadų bei pjūvių. Daromos spalviškai arba grafiškai. Dažniau spalvinami juodraščiai, nes spalvotus švarraščius sudetinga dauginti, publikuoti, bet jie vaizdesni. Nera bendros simboliu ir spalvu sistemos. Buvo pasiūlyta Ž. Simonavičiaus, bet labiau paplito kilusi iš Čekoslovakijos.

Purlys, E., 1972: fiksuojant elemento liekanas pagrindžiamas jo atkūrimas. Kartais laiko taupymo sumetimais fiksavimas gali būti užbaigiamas vykdant restauracijos darbus. Fiksuojamas elementas priskiriamas konkrečiai istorinei objekto rekonstrukcijai. Neaptikus jokio elemento, nustatomas sluoksniavimasis ir pirminis mūras. Pateikiama statybiniu medžiagu charakteristika, mūro savybiu analizè, pagal kuria jis priskiriamas stilistinei epochai. Tai apytikris datavimas, jeigu jis nepagristas istoriniais duomenis. Fiksavimo būdas turèty büti pasirenkamas priklausomai nuo informacijos, gaunamos zonduojant, pobūdžio. Aptikus elementus darytini brëžiniai, kartu aprašas ir fotofiksacija (zondo kortelè). Nesant elemento pildytina müro kortelè su aprašu ir fotofiksacija. Apibendrinant gauta informacija nustatoma pastato mūro struktūra šiuo metu, fiksuojami planu ir fasadu pokyčiai kiekviename evoliucijos etape (pateikiamos planų ir fasadu stilistinès kartogramos, 
retrospetyviniai brëžiniai ir ataskaita). Fiksacijos metodikos tikslas - maksimalus patikimumas, vaizdumas ir išvadu įtikinamumas.

Drèma, V., 1975: mūro tyrimu rezultatu dokumentacija: a) zonduojant architektas veda dienyna; b) paruošia būtina pagalbinę medžiagą; c) tvarko tyrimu rezultatų dokumentaciją; d) visi mūro zondai pažymimi planuose ir išklotinèse ne mažiau M1:25; e) zondai numeruojami arabiškais skaitmenimis; reikšmingesni zondai fotografuojami su prideta masteline liniuote; $f$ ) surenkami pavyzdžiai cheminiams tyrimams.

Zareckiene, D., 1987: iki šiol PRPI (Paminklu restauravimo projektavimo institutas) nera bendros tyrimy dokumentavimo formos. Dalis specialisty zondus fiksuoja laisva forma, individualiais ženklais, ne visada daro kartogramas, tyrimu ataskaitas. Dalis duomenu lieka neužfiksuota ir nepatenka ị archyvą. Paprastai dokumentavimas baigiasi mūro stilistinèmis kartogramomis, kurios tik konstatuoja, kokia susiklosčiusi paminklo stilistiné sudètis, bet neatsako į klausimus, kokia buvo jo raida, koks išlikimas, atskiru paminklo daliu kompleksine vertè. Kartais duomenys apie elementa išbarstyti po atskiru zondu fiksacijas, nèra apibendrinto jo vaizdo. Naudoti dvejopi sutartu ženklu rinkiniai su ivairiomis variacijomis ir kartu laisva forma. Ne visada apmatuojami zondai. Paprastai naudojamos korteles. Nera bendru sutartu ženklu, tai apsunkina kartogramy skaityma. Retai rengiamos retrospektyvines schemos. Medžiagos kokybe itin priklauso nuo autoriaus profesionalumo, o ne nuo paminklo sudetingumo.

Paruošta instrukcija „Architektūros tyrimu metodiniai nurodymai"su pavyzdžiais, kortelemis, etalonais. Bet ir ši parengtoji metodika kol kas nebuvo patvirtinta kaip oficiali PRPI. Joje apibrèžtas mūro zondavimo duomenu fiksavimas, architektūrinès raidos, elementu irfotozondu korteles, pateiktos ju formos, sutartiženklai mūro stilistinems kartogramoms, retrospektyviniams brėžiniams. Naujas rinkinys parengtas siekiant vaizdumo, lakoniškumo, pratęsimo galimybès, atlikimo paprastumo. Nustatytistilistiniu epochuženklai. Tos pačios stilistinès epochos skirtingoms fazèms žymèti naudojamas tas pats skirtingo intensyvumo ženklas. Žymimi mūrai, autentiškos detalès ir zondu numeriai. Müro stilistinès kartogramos-grafinès natüros tyrimusuvestinès, parodančiosfaktinįįvairiu laikotarpiu išlikimą. Sudètingais atvejais iš ju sunku suvokti raidą ir įvertinti išlikima, todèl reikia atlikti faktine duomenu diferenciacija pagal statybos ir rekonstrukciju etapus. Daromi detalūs fragmentu brëžiniai ir retrospetyviniai brėžiniai, $k u$ riems gali büti panaudotos ir analogijos. Tai mokslinè medžiaga, atspindinti vystymosifazes. Medžiaga galima panaudoti skirtingu faziu išlikimui nustatyti, architektūrinę meninęvertę, restauravimo koncepcijos parengti, architektūros istorijai iliustruoti.

Iki IX dešimtmečio buvo akcentuojamas dokumentavimo lakoniškumo, laiko ir sąnaudų taupumas. Ilgainiui toks akcentas blèso, nes tyrimus bandyta industrializuoti, didinti tyrèjų skaičių. Metodikai svarbiu kriterijumi darèsi galimybè į tyrimus ịtraukti ne tokius pasirengusius ir net visai nepasirengusius „kadrus“. I šią sritị perèjo daug atsitiktinių žmonių, negalejusių rinktis karjeros krypties, priverstų imtis ne tokio prestižinio darbo. Daugelio jų šioje srityje nebeliko, bet tai jai nesudaro nuostolio. Suprantama, šio bei to pasiekti pavyko dèl vieno iš dialektikos - kiekybinių pakitimų perejjimo ị kokybinius - dessnio veikimo. Tačiau igudimas buvo ir liko paremtas kokybiškais ir sparčiais tyrimais.

2002 m. po Rusijos ekonominès krizès, atsiliepusios visame Pasaulyje, PRI (Paminklų restauravimo institute, ankstesniame PRPI, dabartiniame PRI Projektavimo ir restauravimo institute) nebeliko jokio tyrimų padalinio, visi (išskyrus vieną) tyrejjai perejo i grynai individualią praktiką, jų kiekis Lietuvoje vèl sumažèjo iki vienženklio skaičiaus, bendros metodikos parengimas tapo dar problematiškesnis. Kai paveldo objektų tvarkyba lokaliai suintensyvejja, kaip buvo ịstojus ị ES iki $2008 \mathrm{~m}$. gale prasidèjusios globalinès krizès, išlikusiems tyrèjams dokumentavimo taupumas laiko ir sąnaudų atžvilgiu vẻl tampa aktualus. Jis aktualus ir paveldo išlikimui, kuriam visada ir visur kaip tik ekonominio klestejjimo laikais iškyla sunykimo grèsmè. Taigi Ž. Simonavičiaus (dabartinio Simonaičio) 1960 m. metodikos paieškų istorijos pradžioje akcentuotas dokumentavimo lakoniškumo principas pasirodè esąs nuolat svarbus.

Dar ir 1971 m. E. Urbonienès tekste matoma lakoniškumo svarba, nes tyrèjų tebebuvo vos keletas, o jiems imta kelti nepaprastai daug imlumo reikalaujančias užduotis. Dokumentavimą objekte ji priskyrè prie kvalifikacijos ir tarpdisciplininio bendradarbiavimo reikalauja nčių tyrimų etapų. Akivaizdu, kad praktikuotas zondavimo organizavimas naudojant žemos kvalifikacijos darbo jeggą, nes vis rašoma apie didelių mūro plotų atidenginejjimus ir mūro, bet ne architektūros tyrimus.

Tyrimų skaidymas ị ,,argumentus“ ir „išvadas“ rodo bandymus jiems suteikti daugiau moksliškumo ir kartu galimybes tyrinèti mažai igudusiems, nes patyrę iškart mato „išvadas“, jiems nereikia dirbtinai ties kiekvienu zondu išvedžioti „argumentu““, tai prieštarauja lakoniškumo kriterijui (juk biologas, pavyzdžiui, stebèda- 
mas kad ir gerai pažįstamą keturkojị naminį žinduoli plèšrūną, užuot detaliai aprašinèdamas jo savybes, kad argumentuotų jo tapatybę, rašo tiesiog „šuo“). Argumentai ir išvados galètų būti surašyti vieną kartą visam objektui galutinejje tekstinèje ataskaitos dalyje, kuri turètų būti lakoniška, ne atkartoti to, kas matoma brěžiniuose, o tik glaustai komentuoti.

Dèl taupumo fotografuotini ne tik charakteringi zondai, bet visi zondai (arba bent didžiuma, kaip 1960 m. rašè Simonavičius). Anais laikais, kai ranku darbas vertintas mažiau negu automatizuotas, siūlymas fotografuoti tik ypatingais atvejais suprantamas, bet dabar, kai fotografavimas yra visuotinai prieinamas ir paprastas reikalas, fotografuoti deretų kuo daugiau. Ir dar dèl teisinių principu ịsigaliojimo - nuotrauka labiau pretenduoja ị įrodymą negu piešinys.

Kartogramos, kurios ir liko pagrindiniu suvestiniu tyrimų dokumentu, vadintos "mūro“, „mūro stilistinemis“ arba „istorinèmis stilistinemis“ kartogramomis. Tai netikslu, nes tiriami objektai ne visada mūriniai, mūriniuose objektuose yra svarbių autentiškų dalių, padarytų iš kitokių medžiagų, mūras ne visada išreiškia stilių, o dažniausiai visai neišreiškia. Mūrininkas juk paprastai neturi jokio supratimo apie stilius. Nemūrinès dalys mūre menkai vertintos - juk paveldotvarkos veiklos pagrindiniu tikslu laikytas restauravimas, vadinasi, tyrejjas turi atsekti kuo ankstyvesnes mūro formas. Jos tada restauruojamos ir užpildomos atitinkamos epochos archetipus atitinkančiais imitaciniais medžio gaminiais, o tegul ir vèlyvesni, bet autentiški gaminiai likviduojami. Dabar linkstama prie kitokių principų, nuolat gyvavusių visoje Vakaru Europoje. Todèl atpažinti ir dokumentacijoje priskirti prie statinio raidos etapu medžio ir kitus trapius nemūrinius gaminius, dangas, apdailas bütina.

Lietuvoje su stilistiniu grynumu visada buvo striuka, dažniausiai stiliaus elementai diegiami formaliai, mechaniškai, dažnai viename objekte sumaišomi kelių ideologiškai nesutaikomu stiliu elementai, nes ideologija mums paprastai nesvarbi, nesuvokiama, svarbiausia - kiek įmanoma neatsilikti nuo vakarietiškų madų. Net specialistais laikomi asmenys tai menkai suvokia, todèl, pavyzdžiui, rašoma „rokokas, arba vèlyvasis barokas", nors abu šie stiliai visiškai skirtingos kilmès, pirmasis - prancūziškos, antrasis - itališkos. Yra daug vietinių pavyzdžių, kur viename objekte suveltos istoristinès ir secesinès formos, kurios yra visiškai nesutaikomos, nes pats žodis „secesija“ reiškia atsiskyrimą, suprask - nuo istorizmo principų.

Dèl šių priežasčių ir didesnio saugumo, kad tyrimai nenukryptų i grožinès literatūros sritị, kartogramos nevadintinos „mūro“ ar „stilistinèmis“, o ir „,istorinèmis", nes nuolat striuka ir su istoriniais šaltiniais, o verčiau jas vadinti tiesiog „raidos kartogramomis“. Vietoj abejotinų stilių pavadinimų kartogramų legendose galima rašyti raidos etapų numerius eilès tvarka, jeigu yra duomenų, susiejant jas su istoriškai nustatytomis rekonstrukcijų datomis, apytikriais galimais rekonstrukcijų datavimo periodais arba, dar smagiau - su galimais vietiniais istoriniais valstybès raidos periodais, kaip nuo seno daroma Vakaruose (pvz.: Tiudorų, Viktorijos, Habsburgų periodai - Jogailos, Poniatovskio, Muravjovo periodai ir t. t.).

Kalbant apie fasadų kartogramas - jų braižymas paprastai kertasi su bendra kartogramų vaizdavimo logika. Juk fasaduose paprastai matomos tik pačios vèlyviausios apdailos, išskyrus išzonduotas ar savaime atsidengusias vietas. Tai tik tokios fasadų vietos ir žymètinos simboliais fasadų kartogramose, antraip susidaro neleistina painiava.

Kalbant apie kartogramų simboliką - jeigu liausimès priskirinèti statinio raidos etapus prie stilių, nebus prasmès naudoti stilistinius laikotarpius simbolizuojančius žymenis. PKZ, pavyzdžiui, etapus žymi tiesiog didejančio intensyvumo linkme pagal senumą, nenustygstantis Simonaitis (buv. Simonavičius) - vaivorykštès spalvinès gamos principu, taip iliustruoja statybos technikos ir formų evoliuciškumą.

Spalvų naudojimas kartogramose dirbant su vektorinemis braižybos programomis ir naudojant šiuolaikinę spausdinimo bei leidybos techniką nesukelia jokių problemų. Vaizdumas gali nebebūti aukojamas dauginimo patogumui. Priešingai - maketuojant brèžinius kompiuteriu spalvas būtina naudoti kaip techninę priemonę, ir tuo patogiau, kuo jos kontrastingesnès. Be to, galima ir patartina skirtingų raidos etapų duomenis braižyti skirtinguose sluoksniuose, taip padidinti vaizdumą ir sudaryti galimybes bet kada be didelių pastangų kartogramas paversti retrospektyviniais brèžiniais, lengvai pasiekiant maksimalų vaizdumą, kurio taip pasigesdavo tyrimų metodikos paieškų pirmtakai.

E. Purlio $1972 \mathrm{~m}$. pastebetą poreikį fiksavimą pratęsti ir užbaigti tvarkybos darbų metu kaip tik sèkmingai gali patenkinti kompiuterinès grafikos naudojimas. Negalima nepritarti, kad fiksavimo būdas turètų būti pasirenkamas priklausomai nuo informacijos, gaunamos zonduojant, pobūdžio. Jis turètų būti maksimaliai lanksčiai pasirenkamas pagal visame objekte gaunamos informacijos pobūdị. Nebūtina nustatinèti jokių formalių taisyklių, kaip teigè ir Ž. Simonavičius, jos tik suvaržytų techniškai parankesnių būdų diegimą. Negalima nepritarti E. Purlio minčiai, kad fiksacijos 
metodikos tikslas - maksimalus patikimumas, vaizdumas ir išvadų įtikinamumas - jai (metodikai) keltini tik tokie reikalavimai.

Atsiliepiant $\mathfrak{i}$ V. Drèmos mintis galimos tokios pastabos: a) zonduojant (geriau - tyrinejant, nes tyrimai nèra vien ardomieji, ir zondavimo turi būti kuo mažiau, kad mažiau būtų pakenkta tiriamam objektui) tikrai pravartu vesti dienyną (mintis, palaikyta ir Urbonienès su Simonavičiumi, ji vadinusiu tyrimų kronika), o žymèti tikslias abrisų darymo datas būtina, fotofiksacijos datavimas vyksta automatiškai, naudojant skaitmenines kameras; b) apie jokius tyrimus be pagalbinès medžiagos kalbèti net nèra prasmès kaip ir be tyrimų rezultatų dokumentacijos tvarkymo; c) privalomo mastelio nustatymas fiksuojant, kai naudojama kompiuterinė grafika, visai nereikalingas, svarbu tik kad būtų užtikrintas reikiamas informacijos kiekis, mastelio keitimas bet kuriuo metu įmanomas; d) zondu numeravimas būtinas, o fotografavimas, kaip jau rašyta šiose pastabose, pageidautinas kuo intensyvesnis (ir ne tik reikšmingesnių zondų) bei lengvai iggyvendinamas naudojant skaitmeninę techniką; e) pavyzdžiu cheminiams tyrimams surinkimas labiau reikalingas, jeigu tikrai numatomas restauravimas, nes datavimas pagal medžiagų cheminę sudètị visgi nepasiteisino kaip patikimas, be to, yra labai brangus.

Bendros dokumentavimo formos siekimas buvo svarbus žinybiškai, kol PRPI (dabar PRI) dar turèjo tyrèjų, o dabar jis nei būtinas, nei įmanomas. Priešingai gal net kenksmingas, nes pažabotų metodikos kūrybą, o tai paveiktų techninę pažangą. Juk po fotogrametrijos dar atsirado lazerinè nuotolinè matavimų technika, GPS, LKS ir 3D skenavimas taškų debesies metodu. Ar šios naujovès turètų būti pritaikytos prie senstančių popieriaus marginimo standartų? Su tokia problema jau opiai susiduria archeologai, kurie tokius standartus turi, ju laikymasis jiems (archeologams) nustatytas vos ne kaip moksliškumo pakaitalas.

Dèl ataskaitu archyvavimo ir duomenų išlikimo užtikrinimo: nebesant tyrimų monopolio pagal nekilnojamojo kultūros paveldo apsaugos įstatymą visų tyrimų, kurių vykdymui yra išduoti kultūros paveldo departamento (KPD) leidimai, ataskaitos turi patekti i jo archyvus. Tokiu atveju departamento uždavinys yra tokias ataskaitas išreikalauti, gerai tvarkyti savo archyvus ir pagal LR archyvų įstatymą padaryti juos visuotinai prieinamus. Autorinèms teisèms užtikrinti galètų būti taikomas archeologijos paveldo tarptautinių rekomendacijų siūlomas principas - jeigu tyrimų autorius per dvejus metus nuo atradimo padarymo nesuskumba publikuoti jo medžiagos, jis (autorius) praranda autorines teises i jo (atradimo) publikavimą, nes atradimai turi teisę būti publikuoti.

Kortelès gali būti naudojamos, jeigu tai tyrejui patogu, tačiau neturètų būti privalomos jų formos, kad nevaržytų kūrybinès iniciatyvos. Jos turi ir negatyvių savybių, viena blogiausių - verčia zonduoti iki atviro mūro, o to darymas be būtinybès žaloja paveldo objektą. Kortelès klausimyne paprastai akcentuotos mūro savybès, pagal kurias tradiciškai datuojama. Toks datavimo būdas vienpusiškas, apgaulingas, mažai pagrịstas. Kortelè verčia mūre ịžvelgti neegzistuojančių savybių, tokių kaip, pavyzdžiui, skiedinio spalva. Skiedinys susideda iš daugelio ịvairiaspalvių dalelių. Pati spalvos sąvoka yra buitinio lygmens empirikos padiktuota abstrakcija, nes spalva yra tik medžiagos savybè atspindèti vienokio ar kitokio dažnio šviesos spindulius, vadinasi, priklauso be medžiagos savybès dar ir nuo konkrečios šviesos spektrometrinès sudèties, taigi ir nuo apšvietimo šaltinio, atmosferos cheminès sudèties, reflektuojančių objektų kaimynystès ir t. t.

\section{Datavimas}

Simonavičius, Ž., 1960: tik pamini datavimo sąvoką.

Urbonienè, E., 1971: datuojama pagal mūrijimo technika ir skiedini, bet reikia nuolat sugrizzti prie istorijos šaltiniu ir lyginti zondus visame pastate. Pateikti detalūs tikrai vertingi iš autoritetingų šaltinių surinkti ¡̇vairių epochų mūro technikos pavyzdžių aprašai.

Purlys, E., 1972: kadangi dauguma archyvų žuve arba išsibarstę po visa Europa, rašytiniu duomenu užtenka tik tyrimu pradžiai, natūros tyrimai tampa ypač svarbūs ir igauna istoriniu šaltiniu vaidmenį, tampa datavimo priemone. Reikalingi nauji datavimo metodai. Charakterizuojant statybines medžiagas, atliekant mūro savybiu analizę ir t. t. datuojamas mūras (rišimas, siūles, skiedinys, plytu dydis, spalva ir t. t.) ir priskiriamas stilistinei epochai. Tai apytikris datavimas, jeigu jis nepagristas istoriniais duomenimis. Galima kaupti medžiaga apie statybinių medžiagu kaita ir ją panaudoti datuoti. Radiokarboninis metodas nerra labai tikslus.

Drema, V., 1975: zondavimo duomenu istorinis ir stilistinis apibrèżimas daromas ne intuityviai, o naudojant analogiško mūro daviniu katalogus (būtina parengti). Dažnai datavimai būna abejotini. Negalima pasikliauti vien plytu matmenimis ir rišimo būdais. Dar datuoti reikia skiedinius. Datuojant reikia remtis ivairiomis disciplinomis. Jei visi trys rodikliai: plytu matmenys, rišimo büdas ir skiedinio sudetis sutampa su katalogo rodikliais, galima datuoti. Katalogas nuolat tikslintinas. 
Zareckiene, D., 1987: nenagrinëja datavimo problematikos.

Igudimas datuoti pagal mūrą tikrai yra labai vertingas, igyjamas igavus daugiametès patirties. Tačiau kiekvienas tiriamas objektas yra išimtis iš taisyklių. Mūrui dažnai naudojamos antrinès ankstesnių epochų plytos. Vietinès plytų gamybos tradicijos dažnai stipresnès už laiką, tai reiškia - skirtingose Lietuvos vietose nesikeitusios iki kelių šimtmečių. Tenka tyrinèti ir ne Lietuvoje, arba vietovèse, kurios kelis šimtmečius priklause kitoms valstybèms ir buvo sugrąžintos Lietuvai.. Skiedinys priklauso ir nuo vietinių medžiagų, nuo laikmečio ir vietovès ekonominès būklès, kartais mūre nei plytos, nei skiedinys išvis nenaudojamas. Mūro savybes gali nulemti ir atsitiktinai atvykusių meistrų tradicijos, užsakovo pretenzijos, architekto principingumas. Pavyzdžiui, vieno iš klasicizmo pagrindejjų L. Stuokos-Gucevičiaus naudotas mūras yra mažiausiai tipiškas klasikinès mūro technikos atvejis. Drastiškai perstatinedamas ištisus kompleksus jis naudojo ypač daug antrinių plytų, reikalaudavo švediško smiltainio, kurị gausiai naudojo Vilniaus katedroje, importo.

Tenka tyrinèti ir nemūrinius objektus (akmens blokai, betonas, medis, fachverkas ir kt.).

Todèl teisus yra E. Purlys, tvirtindamas, kad datavimas pagal mūrą be istorinių duomenų yra apytikris, ir V. Drèma, užsimindamas, kad datavimas yra tarpdisciplininè užduotis. Pastaroji užuomina yra platesné, bet dar platesniu datavimo, dar geriau - identifikavimo (nes svarbu ne tik nustatyti statybos laikmeti, bet ir pažinti objekto bei jo dalių prigimtį, kuri vèlgi padeda patikslinti laikmetị) principu kaip ir kriminalistikoje gali būti indukcija (iš lotyniško inductio - „užvedimas, paskatinimas" - formaliosios logikos metodas apibendrinti skirtingus faktus ị bendras išvadas) + dedukcija (iš lotyniško deductio - „išvedimas“ - formaliosios logikos metodas apibendrinimus išskleisti $i$ atskirus sprendinius arba kitus, platesnius apibendrinimus). Nes identifikuojant autentą kaip ir kriminalistikoje ìrodymai gali būti pateikti arba prielaidos paniekintos remiantis bet kokia smulkmena, kurios neimanoma iš anksto numatyti, o galima tik del pastabumo ir patyrimo lengviau ir greičiau tai padaryti ir išvis padaryti.

Datuoti, be mūro, kitų konstrukcijų ir apdailos technikos, gali padeti patalpu írangos technikos, stilistikos, puošybos ir jos technikos, statinių ir urbanistikos tipologijos nagrinejjimas ir t. t. Absoliučiai tikslus, vienerių metų tikslumo yra dendrochronologinis datavimas. Lietuvos istorijos institutas kartu su fizikos institutu kuria visiškai naują keramikos išdegimo datavimo techniką pagal sunkiujų elementų skilimo puspe- riodị, kuris leis datuoti maždaug $100 \mathrm{~m}$. tikslumu. Tai žymiai tiksliau už radiokarboninį metodą, o tyrejjams nesutariant net dèl mūrinès statybos pradžios Lietuvoje tai jau gana tikslu.

Dèl suminètų priežasčių tiriančiam architektui pravartu turèti žinių iš tokių sričių, kaip istorija, dailès istorija, karybos istorija, technologijų istorija, archeologija, antropologija, lyginamoji kultūrologija, religijotyra, filosofija, psichologija, etnografija (įskaitant vietinių kalbų ir slengų supratimą), fizika, chemija ir t. t. Remiantis tokiomis žiniomis jis turetų pažinti savo srities profesinius principus, galiojančius dabar ir galiojusius visose ankstesnèse epochose. Kitaip sakant, nuo projektuotojo, dirbančio trijų koordinačių sistemoje, tyrëjas skiriasi tuo, kad dirba su papildoma ketvirta - laiko dimensija. Visa šia dimensija jo darbas yra sudètingesnis už projektuotojo, nes tyrèjas privalo turèti dar ir pakankamai patyrimo projektavimo srityje, kad suvoktų, kokių duomenų reikia iš tyrimų.

Be to, jis turi turèti pasižymèti fizine jèga ir ištverme, neturèti daugybès fobijų arba sugebèti efektyviai jas slopinti.

\section{Natūros tyrimų technologija}

Simonavičius, Ž., 1960: neužsimena, nors tikrai turi ką apie tai pasakyti.

Urboniene, E., 1971: tyrimai vykdomi etapais. Žvalgybiniai vykdomi iš išorès, eiliniai, arba privalomieji, - ir iš vidaus. Išplèstiniu, arba detaliuju tyrimu, vykdomy "pilnos"(straipsnio autoriaus kabutes rašomos dèl sąvokos šiurkščios neatitikties dabartinèms lietuviu kalbos normoms, bet ši sąvoka tada buvo normatyvine, toliau ir kitur tekste ji paliekama be komentaru - aut. pas.) objekto restauracijos atveju zondu skaičius neribojamas. Surenkama tekstinè ir grafine medžiaga apie tirti numatoma objekta, atliekama fotofiksacija ir apžiūra, kurios kruopštumas neturi priklausyti nuo numatomo tyrimų detalumo. Ją geriausia pradèti nuo rūsių ir baigti pastoge. Juose daug informacijos, nes dažniausiai būna netinkuoti. Gerai, kai apžiūroje kartu dalyvauja kitu specialybiu tyrejjai.

Jei objektas netyrinètas žvalgybiškai, pirmieji zondai numatomi išorèje, sandūros su kaimyniniais pastatais vietose, kur mūras mažiausiai nukentejęs, kad bütų nustatytas statybos laikas. Tada tikrinamos angos, ju pokyčiai (forma ir vietos). Nustačius angos pakitima bütina nustatyti, kiek jos išlikusios. Tikrinama, kurios sienos autentiškos, kurios pristatytos vèliau. Tam tikslui tikrinama sienu susikirtimuose, atidengiamos mūro juostos sienos viduryje. Kartu patikrinama ir vidaus angu 
padètis. Juostos kalamos patogiame aukštyje. Ieškoma skliautu pédsaku kalant vertikalias juostas iki lubu. Radus pédsaka aiškinamasi skliautu forma. Radus arkinę sarama nustatinejama ne tik jos forma, bet ir gylis, nustatoma, ar tai anga, ar niša (giluminiai zondai). Jie daromi ir itariant ant sienos apdaila. Fasadams tirti naudojamos laipiojimo ar pakélimo priemones.

Purlys, E., 1972: labiausiai paplitęs tyrimu būdas sienu zondavimas. Tai atsakingas etapas, nes nuo jo priklauso informacijos kiekis ir kokybe, pastato saugumas. Kad išliktų spalvine puošyba, būtina išanksto jos paieš$k a$. Tinkas zonduojamas pasluoksniui, taip nepakenkiama tapybai ir aiškiau atskleidžiamas sluoksniavimasis. Visi sluoksniai zonde eksponuojami, kad galima būtu lyginti su kitais zondais. Aptikus dekora zondavimas nutraukiamas.

Drèma, V., 1975: turètu būti kuo mažiau nukalama tinko, pagal galimybes naudoti termovizines kameras.

Mūro zondavimo uždaviniai: pirminès statybos technikos ir jos išlikimo nustatymas; pirminiu konstrukciniu ir stiliaus formu pažinimas; vèlesnių rekonstrukciju müro technikos skirtumu atskleidimas; visu vèlesniu rekonstrukciju architektürinių ir stilistiniu formu katalogo sudarymas; planines struktūros ir funkciju raida; visu techniniu ir architektūriniu pakeitimu chronologijos nustatymas; vertingiausio ir geriausiai išlikusio raidos etapo nustatymas; pažeidimu priežastys. Zondavimas turi büti vykdomas planingai, prieš tai susipažinus su medžiaga.

Paiešku darbo plano klausimai: pamatai (kilmès laikotarpis, techninés ypatybès, pirmine plano sistema, aukštutinè išlikimo riba, jei antžeminè dalis vèlesnè); rūsiai (kilmés laikotarpis, technines ypatybès, pirmine plano sistema, kiek ji skiriasi nuo pamatu ir antžemines dalies plano sistemos, pirminis grindu ir skliautu horizontas, vèlesni pakeitimai, müru vèlesni pakeitimai, mūru sandūros su pamatais ir antžeminès dalies mūru, jei nèra vienalaikiai); antžemines dalies sienu ir skliautu mūrai (kilmes ir rekonstrukciju laikotarpiai, technines ypatybès, jeigu skiriasi nuo rūsio mūru, rekonstrukciju müru techninès ypatybès, pirminé plano struktūra, pirminis grindu ir lubu horizontas, pirminiu langu angu dydžiai, proporcijos, tipai, angokraščiai, išsidestymas, vèlesniu langu kompoziciniai pakeitimai, pirminiu laiptu narveliu struktūra, padètis, pakeitimai, stiliaus elementai: skliautu tipas, nišos, kontraforsai, lizenos, piliastrai, cokoliai, karnizai, kolonos, orderiai, portalai, sandrikai, krosnys, židiniai, dūmtraukiai, ventiliacijos ir akustiniai kanalai, angu apvadai, konsolès, frizai, fasetes, rozetes, girliandos, vainikai ir t. t., sudaromi elementu katalogai); pastoges (tikrinama, ar nebuvo pašalinti viršutiniai aukštai, atikai, frontonai, pastogiu liukai ir t. t., kiek liko pirminio gaisrasieniu mūro, kiek jis rekonstruotas, ar frontonuose liko dekoro, kiek frontonu ir gaisrasieniu sienose liko gretimu pastatu elementu, ar galima iš frontonu ir gaisrasieniu nustatyti pirminio stogo struktūra, ar buvo palèpé gyvenama ar naudojama sandèliuoti, tikrinami jos langai, keltai ir t. t., pirminè dūmtraukiu sistema ir pokyčiai).

Mūro technikos tyrimai zonduojant: mūras zonduojamas tik pabaigus dažymo ir tinkavimo zondavimus; tam tikrais atvejais galima dirbti kartu su polichromijos tyrejais; visada dirbama kompleksiškai su polichromijos tyrejais, neatsietai; kai kertamas tinkas, jis nuimamas pasluoksniui, kad nebūtu pažeisti iš tinko suformuoti elementai; šalinant seniausia tinko sluoksnị reikia nustatyti, ar jis vieno laiko su mūru; mūro technikos pažinimui ir sandūroms atskleisti pakanka atidengti mūro paviršių.

Giluminis zondavimas atliekamas, kai reikia: pažinti giluminę mūro struktūrą, parodyti sienų dubliavimą, nustatyti vèliau primūrytus elementus, atskleisti užmūrytas nišas, angas.

Prieš imantis zondavimo reikia išnaudoti savaimines atodangas. Nustačius elementų nukapojimus ar nugriovimus reikia nustatyti ilgųjų plytų šaknelių išlikimo gylį, kad galima būtų nustatyti prarastą formą. Zonduojant kartu fiksuojamos visos deformacijos, pažeidimai. Atlikus zondavimą visos deformuotos vietos profilaktiškai sutvirtinamos. Neleistinas joks nepateisinamas autentiškos substancijos pašalinimas.

Zareckiene, D., 1987: išankstiniai tyrimai turi nustatyti statybos pirmuma, statybos ir rekonstrukciju etapus, išlikima. Tyrimu programa rengiama pagal istorinius, ikonografinius, literatūrinius, grafinius ir natūros tyrimu duomenis. Sudetingais atvejais nustatoma dvieju etapu tyrimu programa. Pradiniai tyrimai vykdomi

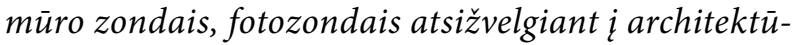
rinę raida.

Išnagrinejjus architektūrinès kompozicijos dèsningumus sudaromas zondu išdestymo grafinis tinklelis. Praktika parode, kad taip galima rasti daugiau kaip $50 \%$ architektūriniu ir dekoratyviniu elementu, visus statybos etapus ir beveik visas rekonstrukcijas.

"Pilnos" apimties tyrimai daromi sudetingiems svarbiems paminklams, kuriuos numatoma restauruoti. Vykdomi atlikus istorinius, polichrominius tyrimus, architektürinius ar bent dalinius archeologinius matavimus. Apimtis ir paiešku vietos nustatomos pagal išankstiniu tyrimu duomenis. Taip galima iš anksto pažinti tiriamo objekto struktūrą, suplanuoti zondu skaičių, 
nustatyti svarbias vietas, sutaupyti darbo sanaudas ir palikti pakenčiama fasadu išvaizdą.

Daugelis elementu būna pakitę arba sunykę. Tyrimai leidžia atkurti retrospektyvinị vaizda, kuris sudaromas pagal architektūrinès kompozicijos dèsningumus: simetrija, tipiškumas, tipiniu elementu atitinkamumas. Bütina nustatyti, ar tiriamas elementas tipinis ar individualus, tada galima nagrineti elementu tipus. Daugelis architektūros elementu simetriški vertikalios plokštumos atžvilgiu ir nesimetriški horizontalios. Jei išlikusi simetriška puse, antros pusès retrospektyva laikytina moksliškai pagrista. Kartais būna išlikę simetrišku pusiu fragmentai, tada nagrinejamas ryšys tarp jų. Kai mažai išlikęs elementas tipinis, galima nagrinèti jo liekanas.

Kai elementas netipinis, nagrinejamos analogijos. Tada retrospekcijos patikimumas priklauso nuo analogo atitikimo ir nuo išlikusios elemento dalies dydžio. Elemento retrospektyvinio vaizdo sukūrimo operacijos: tipiniu elementu ir pagrindiniu architektūros, konstrukciju ir dekoro parametru nustatymas, blogai išlikusio elemento tipo atpažinimas, elemento retrospektyvinio vaizdo sukürimas remiantis to tipo duomenimis. Tipiniu elementu analogija taikoma tik tam pačiam paminklui. Ir individualūs elementai dažnai paklūsta tiems patiems konstrukciniams objekto ir ịrangos dèsningumams.

Iš sudetinių dalių nustatymo ir sąrašo sudarymo susideda elemento tyrimu programa. Juos išanalizavus buvo sudarytos įvairiu elementu tyrimo programos (anketiniai klausimai): langu, duru, nišu, fasadu ir interjeru dekoro, perdangu, jungčiu, stogu, ventiliacijos irangos, laiptu ir statybiniu medžiagų.

Mažai ką bederètų pridèti, nebent tai, kad kelia abejonių tinklelio metodas. Jis nebent tinkamas pradedantiesiems tyrèjams, kurių antplūdžio tikètasi IX dešimtmetyje, padrąsinti, kad viską galima surasti. Išvis neturètu būti orientuojamasi i ardymus - jie tik kai kuriais atvejais neišvengiama skausminga būtinybè.

Tyrimų etapiškumas dabar yra nustatytas kultūros ministro įsakymu IV-259, todèl diskutuoti dèl to per vèlu ir netikslinga, nes jis nustatytas iš esmès teisingai: žvalgomieji, detalūs ir papildomi tyrimai. Prie žvalgomųjų priskiriami ir detalūs dalies objekto tyrimai. Papildomais vadinami tie tyrimai, kurie tęsiami tvarkybos darbų metu.

Niekaip negalima sutikti su pirmtakais dèl to, kad žvalgomieji (dar žargoniškai vadinti „pirmos eilès") tyrimai vykdytini iš išorès, o detalūs - ir iš vidaus. Toks skaidymas padiktuotas akivaizdžiai tik realių gyvenimo sąlygų. Kol pagal planinę tvarką neiškeldinti gyventojai, tenka tenkintis tyrimais iš išorès, o tik paskui galima imtis vidaus. Remiantis pradiniais tyrimais būdavo rengiami rekonstrukcijos projektai, be kurių patvirtinimo nebuvo įmanomas patalpų tuštinimas, o juk iš esmès pastato raida atsiskleidžia būtent iš jo vidaus ir ji (raida) turètų lemti projekto sprendinius. Tyrimų iš išorès įspūdžiai turi įtakos nebent kosmetikai, kurią kaip tik tinka palikti spręsti gale, kai esminiai sprendiniai jau priimti ir igyvendinami. Tada paprastai būna sumontuoti pastoliai, kuriais naudotis patogu ir saugu, nereikia naudotis pakèlimo ir karstymosi priemonemis.

Nieko nerašyta apie technines priemones, gal laikant, kad tai juodadarbių reikalas. Reikètų keisti požiūrị ir juodu darbu laikyti kaip tik labiau kameralinius, o ne lauko darbus, nes būtent jie teikia visą informaciją. Tyrejas neturètų išeiti iš objekto nepadaręs išvadų arba sugrịžti i jij tol, kol išvadas padarys, nes retai tai pavyksta padaryti sedint prie kompiuterio arba braižybos stalo.

Patarimai: ịrankiai turi būti grūdinti vandeniu, o ne alyva - nors tai ne taip saugu dèl galimo ašmenų skilinėjimo, bet užtikrina efektyvesnị atidenginèjimą, mažesnę vibraciją; juos galąsti būtina iki dalgio aštrumo ir jo pustymo tvarka - palaipsniui trumpinant galandinimo intervalus iš abiejų ašmens pusių; i tiriamą objektą irankių reikia pasiimti tiek, kad planuotą dirbti laiko tarpą ašmenys neprarastų reikiamo aštrumo. Visa tai svarbu dẻl mažesnio objekto sužalojimo garantijų ir laiko bei sveikatos taupymo; labiausiai tinkama plaktuko galvute yra $800 \mathrm{~g}$ svorio. Reikia turèti atsargini plaktuką arba papildomai gerai pagaląstą mūrininko kirtiklị, kuris itin pravartus dirbant dideliame aukštyje, kai viena ranka reikia už ko nors laikytis; reikia pasiimti atsarginę matavimo priemonę, geriausia kitokio tipo (pvz., $10 \mathrm{~m}$ ruletę ir rankinị 60 m lazerinị matuoklį); kartu dar ir dèl saugumo reikia turèti atsarginį nepriklausomą šviesos šaltini, jị nuolat laikyti su savimi.

\section{Darbo sauga}

Nè viename šaltinyje neaprašyta, o ji svarbi. Greta būtinybès turèti atsarginị šviesos šaltinĭ, paminètinos kitos svarbiausios taisyklès: eiti į pavojingą objektą saugiau ne mažiau kaip dviese; visada bent vienam neabejingam asmeniui pasakyti, kur eini ir kada planuoji grịžti; turèti su savimi individualias ryšio priemones gerai įkrautais akumuliatoriais; vykti ị objektą saugiau automobiliu su automatine pavarų dèže, nes jị valdyti galima viena likusia sveika ranka ir viena likusia sveika koja; kur nors lendant partnerị palikti išorẻje; 
itarus degių ar sprogių dujų kvapą nesinaudoti ugnimi, elektros prietaisais, kibirkščiuojančiais įrankiais; zonduojant mūvèti pirštinèmis su gumuotais delnais; naudotis respiratoriais ir apsauginiais akiniais, jeigu tokie tinkami tyrimams kada nors bus išrasti; kur nors lipant ant atramos laikyti vienu metu ne mažiau dviejų galūnių; lipant per paklotą, koją statyti vienu metu ne mažiau kaip ant dviejų lentų; visada karstytis tik plikomis rankomis; krentant labiau saugoti stuburą ir galvą, o ne galūnes; pagal galimybes nestatyti laipiojimo priemonių virš aštrių ir kietų daiktų; visada duoti nukraujuoti atvirai žaizdai; nepalikti ardymo priemonių už regèjimo lauko ribų ir ị ièjimo ị patalpą angos pusę nuo savęs; neleisti sau prarasti daugiau 2,5\% kūno skysčių; su muilu ar šampūnu praustis tik kitą dieną po ardomųjų tyrimų; prisiminti, kad lauko darbai yra ne tokie kenksmingi sveikatai kaip kameraliniai darbai, todèl nepatartina pastarųjų tęsti po 23.00 val. arba pasiekus 160:95 mm kraujospūdị.

\section{Urbanistika}

Urboniené, E., 1971: atliekant žvalgybinius tyrimus paprastai tikslas yra išsiaiškinti sklypo užstatymo evoliuciją, atskiru korpusų vertę, išskirti saugotinus pastatus bei ju fragmentus, o ne atskiro pastato savybes.

Ar dèl pavardès ir disciplinos pavadinimo kilmès kalambūriško sutapimo ji vienintelè užsiminè apie architektūros tyrimų urbanistinị aspektą? Tik turètų būti žiūrima priešingai: ne urbanistika yra pradinių tyrimų objektas, o architektūros tyrimai turètų būti urbanistinių tyrimų sudedamąja dalimi kartu su kitų disciplinų tyrimais.

\section{Išvados}

1. Natūros tyrimai svarbūs tuo, kad jų pagrindinis uždavinys yra nustatyti autentiškumą, kuris yra pagrindinè bet kurio kultūros paveldo objekto vertingoji savybè. Lietuvos atveju jie itin aktualūs dèl rašytinių šaltinių apie architektūros bei urbanistikos paveldą skurdumo ir nepalankių jo išlikimo sąlygų.

2. Šiu tyrimų tikslu neturi būti vien paveldo objektų restauravimas, nes jis nera prioritetinè paveldosaugos tvarkomụjų darbų kryptis. Realios socialinès sąlygos verčia iškilti daugybę tyrimų šalutinių tikslų, kurie taip pat negali būti ignoruojami.

3. Bandymai unifikuoti dokumentavimo formą paprastai būdavo žinybiškai motyvuoti. Besivystant technologijoms bandymas tai padaryti bet kuria kaina gali atimti galimybes diegti technines naujoves, leidžiančias didinti tyrimų efektyvumą ir metodikos optimi- zavimo kūrybines paieškas. Svarbiausia, kad pasirinktas dokumentavimo būdas ir bendrai tyrimų metodas leistų geriausiai išreikšti tiriamo objekto savybes.

4. Nežiūrint didelio Lietuvos specialistų sukaupto patyrimo datavimas vien pagal mūro ypatybes yra apgaulingas, vienpusiškas ir fiziškai žalojantis paveldą. Suabsoliutinus tokị datavimą nuvertinama natūros tyrimų disciplina iki masiško, paviršutiniško, nors ir planingo, padienio darbo lygio. Efektyvus datavimas galimas tik dèl specialisto patyrimo ir jo sugebejjimo ivertinti kuo daugiau skirtingos kilmès požymių.

5. Iškalbingesnis tyrimų organizavimo principas yra „iš vidaus ị išorę". Svarbu ne tik jiems gerai pasiruošti studijuojant rašytinius bei grafinius pagrindus, bet ir tinkamai pasirinkti technines priemones rankų darbui objekte, nes jis yra vienintelis informacijos gavimo būdas natūros tyrimuose, reikalaujantis ne žemesnès kvalifikacijos negu kitos darbo grandys.

6. Natūros tyrimuose neužtenka standartinių darbo saugos taisyklių, nes tai yra ekstremalios veiklos sritis.

7.Žvalgomieji architektūros objektų tyrimai gali būti naudingi urbanistikos objektų raidai suvokti, bet išsamesnį urbanistikos tyrimą užtikrintų architektūros objektų visumos daugelio disciplinų tyrimų šaltinių apibendrinimas.

Pastaba. Viliuosi, kad neịžeisti liko jokie garbūs kolegos ir mokytojai, jeigu jų pasaulèvaizdis iš tiesų yra orientuotas istoriškai. Šiuo straipsniu tik siekta bendrais interesais padèti atgyti kebliose istorinese aplinkybèse ịstrigusiai tyrimų metodikai.

\section{Literatūra ir šaltiniai}

Drèma, V. 1975. Preliminariniams architektūros paminklu tyrimams natūroje atlikti instrukcijos projektas. VAA F1019 Ap11 B726. Vilnius.

LR nekilnojamojo kultūros paveldo apsaugos ịstatymas. 2005 04 19, Žin., 2004, Nr. 153-5571 (2004 10 19).

LR kultūros ministro įsakymas „Dèl nekilnojamųjų kultūros vertybių atskleidimui reikalingų tyrimų duomenų apimties aprašo patvirtinimo“. İsigaliojo $20050622 \mathrm{Nr}$. IV-259, Žin., paskelbta 2004, Nr. 153-5571.

Purlys, E. 1972. Lietuvos TSR paminklu natūros architektūriniu tyrimu problemos ir medžiagos fiksacija. Pranešimas konferencijoje (rusų kalba). VAA F1019 Ap11 B721. Vilnius.

Simonavičius, Ž. 1960. Pabaltijo restauratoriu dirbtuvių II-oji moksline-metodine konferencija mokslinès-techninès dokumentacijos sudarymo ir saugojimo klausimu (rusų kalba). VAA F1019 Ap11 B713. Vilnius.

Urbonienè, E. 1971. Architektūriniai tyrimai natūroje. VAA F1019 Ap11 B718. Vilnius.

Zareckienė, D. 1987. Temos „Lietuvos TSR paminklu tyrimu metodiniai nurodymai" ataskaita (rusų kalba). VAA F1019 Ap11 B751. 


\section{PROBLEMS OF LIFE RESEARCH OF ARCHITECTURAL AND URBAN OBJECTS}

\section{R. Zilinskas}

Abstract. The paper deals with previously unpublished problems of life (live) research in architecture. There have been 5 known cases of attempts to develop standards of such a research, and the results of all the attempts are partially preserved and stored in the Vilnius County archive. Analysis of these attemps and suggestions on applying personal and collective experience of predecessors in determining the principles of life (live) research for the current system of heritage are based on the personal 22-year experience of the author of this paper.

Keywords: stylistic restoration, restoring, applied research, historic-artistic development studies, authenticity, valuable property, iconography, heritage, heritage protection, evolution, probe, restoration, conservation, image, morphologic type of buildup, aksiological research, search of polichromy, cartogram, vector program, GPS, LKS, 3D scanning, destructive testing, copyright, dating, induction, deduction, deep sounding, symmetry, representativeness, field work, office work.

\section{ROBERTAS ZILINSKAS}

Dept of Urban Design, Research Laboratory for Urbanistic Analysis, Vilnius Gediminas Technical University (VGTU), Pylimo g. 26/Traku 1, LT-01132Vilnius, Lithuania.E-mail: bebop@ inbox.lt

Internship in PKZ (Poland), 1988. Publications: author of 3 research papers. Research interests: architectural heritage. 